\title{
学院門社区（開封旧内城）の住居類型とその変容に関する考察

\author{
CONSIDERATIONS ON HOUSE TYPES OF XUE YUAN MEN SHE QU \\ (KAIFENG OLD CASTLE AREA) AND THEIR TRANSFORMATION
}

\author{
趙冲*, 布野修司**, 川井操***, 張鷹**** \\ Chong ZHAO, Shuji FUNO, Misao KAWAI \\ and Ying ZHANG
}

\begin{abstract}
This paper discusses house types and their transformation of Kaifeng city in Henan (China), which is known as the capital city of Bei Son dynasty. Authors selected a she qu(Community) of former walled city in the central district of Kaifeng, which is called Xue yuan men she qu at present, as an intensive field study and clarified the types of dwelling units and the transformation process.

The spatial formation of Keifeng at Bei Song dynasty is identified on the present map based on the newest archeological findings. However Kaifeng at that time is buried several meters under the present ground level by many floods. The urban tissues we see now, is formed after flood in 1841. The central area of old castle was still occupied by low rise houses and shop houses until the end of $20^{\text {th }}$ century, but was drastically changed by redevelopment program introducing high rise apartment houses. This paper clarified the changes among decade 2000-2010 as for the targeted area. There existed old traditional form of siheyuan (Chinese quadrangle dwellings), siheyuan like Liu family residence which is only one example left in the area. Most of siheyuan had been destroyed or is shared by several families. This paper classified 103 dwelling units we measured into five groups according to number of rooms and discusses the extension process of living space.
\end{abstract}

Keywords : Kaifeng, the capital city, typology of houses , community

開封，都城，住居類型，社区(ユミュニティ)

1.はじめに

\section{1-1 研究の目的と背景}

本研究は, 都市組織Urban Tissue 研究の一環として, また，「中 国都城の系譜とその空間構造の変容に関する研究」注1) の一環とし て, 中国七大古都のひとつである開封注2（河南省）を対象として, その都市形成過程とその変容について明らかにすることを大きな目 的としている。中国古都の場合、都市組織の単位となる都市型住宅 は四合院となる。しかし，近年は大きく変容しつつあり，「大雑院」 化, 寸なわち, 四合院を複数の世帯が使用することが起こっている。 また, 四合院が分割される変容も起こっている。本稿では, 開封内 城の中心に位置する回族地区の学院門社区をとりあげ, 臨地調查を もとにして, 敷地の型を分析し、住居の型を分析することで, 四合 院とその敷地がどう変容したかを明らかにする。

中国古代の都城の街区の構成原理である「坊牆制」は，北宋の首 都・開封においては最早実態をともなっていなかったとされる。久 保田和男（2007）によれば，「坊牆」は存在したけれど，新たに坊 門や「坊牆」が建設されることはなく, 街路に面して建造物を建て ることは公認されており,「侵害」に悩まされ, 夜禁とともに坊門の
開閉が行われることなく，治安維持，都市住民管理とは無関係であ った。「坊制」の崩壊とともに「市制」も崩壊していく。城市内の 「坊」に場 所を限定さ れていた 「市」は, その場所と 形を変えて いく。全国 的市場が成 立するとと もに,「県」 のなかに， 「鎮」「草 市」「虚市」 「歩」「店」 などと呼ば れ，「鎮市

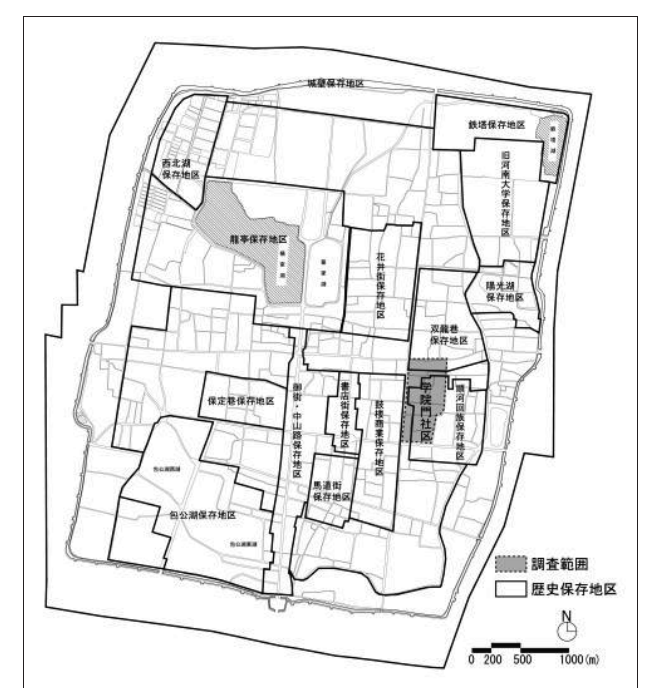

図 1 開封歴史保存地区と学院門社区

\footnotetext{
* 福州大学建築学院 講師・博士(環境科学)

** 滋賀県立大学環境科学部 教授・博士 (工学)

*** 滋賀県立大学環境科学部 助教・博士 (環境科学)

**** 福州大学建築学院 教授・博士(工学)
}

Lecture, School of Architecture, Fuzhou University, China, Dr. Eng.

Prof., Graduate School of Environmental Planning, University of Shiga Prefecture, Dr. Eng.

Assist. Prof., Graduate School of Environmental Planning, University of Shiga Prefecture Dr. Eng.

Prof., School of Architecture, Fuzhou University, China, Dr. Eng. 
(市鎮)」と総称される小都市，集落が発達してくる。

開封の歴史は古く, その名の由来は春秋時代に遡るが, 五代の後 梁の太祖朱全忠が出身地である開封を一旦首都とし注3), 後晋が正式 に首都として以降, 特に後周の世宗芝栄のもとで宋の太祖となる趙 匡胤がその基礎を築いて以降の開封が本稿での考察の対象となる。 しかし, 北宋時代の開封は, 現在, 地下数メートルに埋もれている。 北宋以前には洪水はなかったが, 北宋滅亡後, 黄河は流れを南に変 え, 明代には何度も洪水を受けることになるのである。清代も洪水 の被害は続いた。現在の城壁は, 1841 年の大水害後, 再建されたも のである。

開封の都市形成の歴史, その変遷, そして, 内城内の現況（土地 利用形態, 建築類型の分布) については前稿で明らかにした注4)。本 稿では, 学院門社区の住居類型とその変容について焦点を絞りたい。

\section{1-2 既往の研究}

開封に関する考古学研究として最新成果をまとめたものに, 劉春 迎（2004，2009）がある。また，それに先立って開封市文物考古隊 編（1998）がある。歴史研究としては, 『清明上河図』注5)『東京夢 華録』注6) が残されていることから, 周宝珠（1992，1997）, 程子良 他編（1993），伊原弘編（2003）など比較的数多くの論考がある。

開封に関する日本の研究者の論考としては, 中国語訳もある久保 田和男 (2007) が最も包括的である。また, 一般書として伊原弘 (1991, 2009))がある。さらに, 開封のユダヤ人に焦点を当てた小岸昭(2007) がある。主要な論考については, 遠藤隆俊・平田茂樹・浅見洋二編 （2010）の中の久保田和男が都市史研究について研究史をまとめて おり, そのレビューに委㸚たい。主要な参考文献を末尾にあげる。

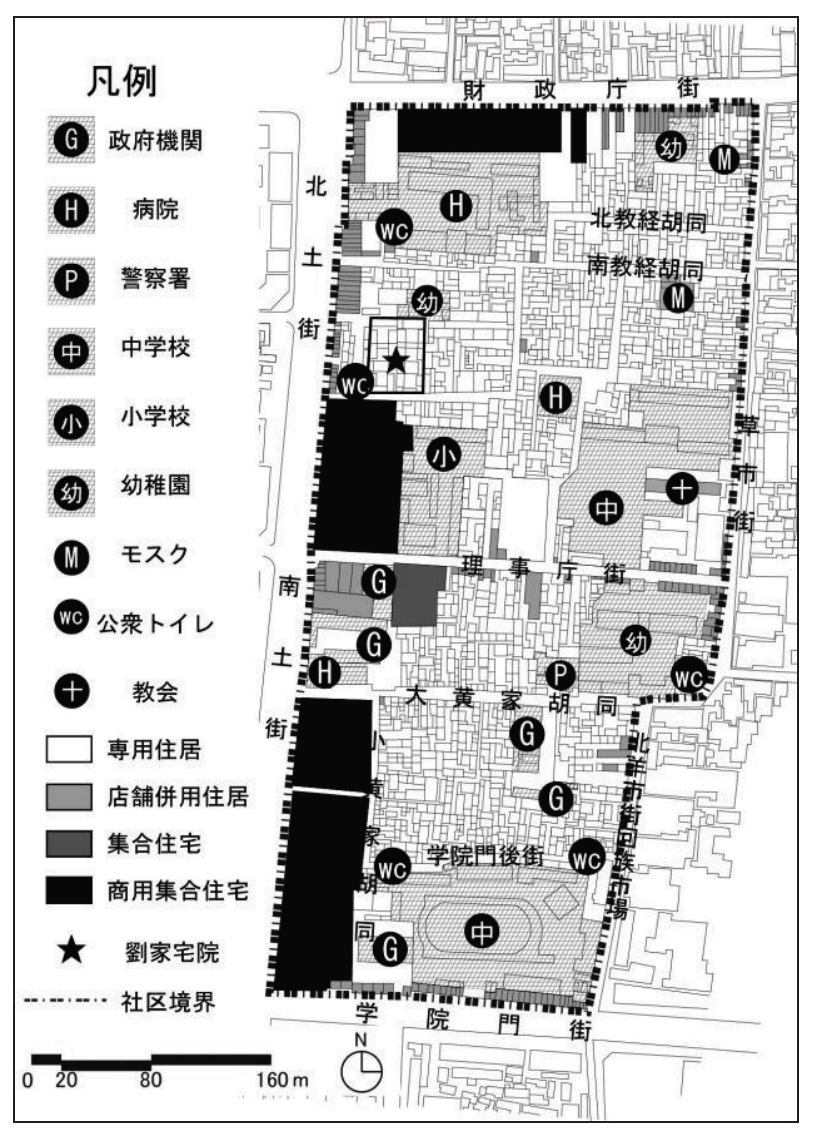

図 2 学院門社区の施設分布（2010 年）
建築学, 都市計画学に関する研究としては,「営造方式」に関する 研究を別とすれば，管見の範囲では，伊原弘編（2003）に収められ た玉井哲雄，小泉和子，高村雅彦らの論考を除くとほとんどない。

\section{1-3 調査概要}

現地調查は, 2007 年 8 月 16 日〜8 日 23 日に東大門地区を中心に 予備調查を行い, 本稿のもとになる学院門地区についての詳細調査 は, 2009 年 12 月に共同研究者である于航注7)が単独で行った。また, 隣接する文殊寺社区と合わせて補足調查を 2010 年 8 月 22 日〜 月 27 日に行った注 8 。

臨地調查は, 2000 年の都市地図 $(1 / 2,000)$ をベースマップと し, 施設分布調査, 建築形態調查（建築階高, 構造形式）を中心に行 い, 住宅については, 学院門社区の 103 世帯について実測調査を行 った。

\section{2. 学院門社区の概要}

開封城内は，鼓楼区，龍亭区，順河回族区，南開区，金明区の 5 つの市轄区からなり, 市轄区は, 複数の弁事処によって統括され,

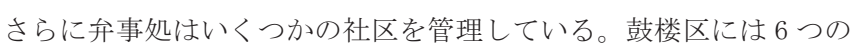
弁事処があり，24の社区からなる。学院門社区はそのひとつであ る。

\section{2-1 歴史的街区としての学院門社区}

学院門社区は, 開封旧城内の中央東部, かつての宋の皇城南西に 位置する。東の草市街と北羊市街, 西の北土街と南土街, 南の学院 門街, 北の財政庁街, に囲われた街区で, 行政組織としては, 開封 市順河回族区に属している。皇城南壁に接する西門と曹門を結ぶ西 大街が真っ直ぐ財政庁街に接続する。学院門社区の西に隣接する文 殊寺社区の中央を南北に走る書店街が，ほぼ皇城東壁のラインに当 たっている。社区の西端を走る北土街・南土街は, 旧封丘門 (北門) につながる南北大通りである。学院門社区は, 開封において最も回 族が集中する地区であり，宋代から 19 世紀末までユダヤ教徒のコ ミュニティがあったとされ, 古来様々な民族が居住してきた地区で ある。

開封市政府は, 1981 年に, 開封の古遺産や文物などを保護する『開 封歴史文化名城保護計画』を中国国家計画局に提出し，1985 年に認 められるが, 学院門社区は, 16 ヶ所の歴史保存地区のうちのひとつ 順河回族保存地区に指定されている。

\section{2-2 学院門社区の施設分布（図 2)}

学院門社区には, 中規模な商業施設 13 があり, 主に地区の南西辺, 北辺に集中している。ホテルが 3 立地する。基本的に大通り（大街） に面するが, 街区の内部に取り囲まれる形のものも 1 棟ある。病院 が 1 ある。

教育施設は, 学院門社区に, 幼稚園 3 , 小学校 1 , 中学校 2 の計 6 あり, 分散している。教育施設の占有面積は大きい。

宗教施設として, 中央にキリスト教会 (1916 年創建), 中央北部 に南教経清真男寺, 北東部に草市街清真女寺がある。さらに, 第四 人民病院内のボイラー室に, かつてユダヤ教会で使われた井戸が確 認でき, 病院南部に隣接する住居には, 開封のユダヤ教にまつわる 資料が一部展示されている。また, 地区外部ではあるが東南部に隣 接して東清真寺 (明初創建) がある。これは開封史上最も古い清真 寺とされ, 1963 年に開封市重点文物保護単位に認定されている。 


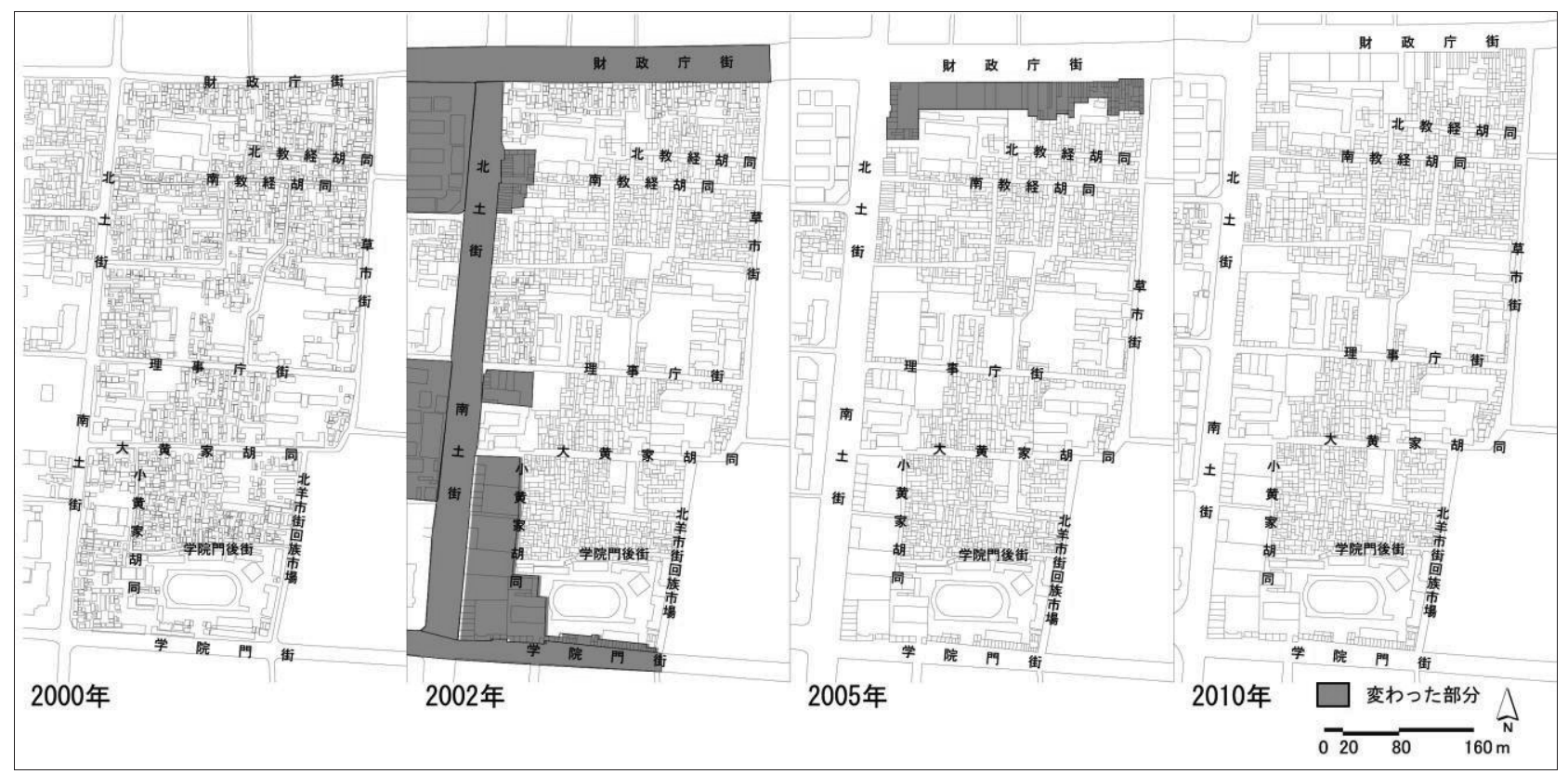

図 3 学院門社区の変容 2000-2010 年

特に学院門社区は，現在でも回族が多く居住する地区である。

\section{2-3 社区の変容}

現在の開封城は 1841 年の大洪水の後再建されたものであるが，城 壁の位置は金代のもので, 明清代, そして現代に至るまで, その城 壁は維持されている。2005 年に城壁に上る馬道が発掘され, 同じ位 置に再建されていることが明らかになっている。

歴史地図として, 比較的詳細なものとして残されているのは, 光緒 33（1907）年の地図が最も古く, 続く, 民国 3（1914）年，民国 8 （1919）年, 民国 $28 （ 1939 ）$ 年, 2000 年の地図を比べると, 清朝末 期の開封は少なくとも 1930 年代までは存続しており, その中心に位 置していた文殊寺および学院門社区は, 1841 年以降の歴史を大規模 な変化なくとどめてきたことがわかる。

しかし, 歴史保存地区に指定されているにも関わらず, 学院門社 区のこの間の変容は激しい。ベースマップとした全ての建
造物の階数が記載された 2000 年の都市地図 $(1 / 2,000)$ を見ると, 行政機関, 病院，学校などの公共施設を除くと，全て 2 階以下の住 宅群で埋め尽くされていることがわかる。

地区の変化をGoogle Earth で追いかけると図 3 のようになる。 まず 2000 年から 2002 年にかけて, 北側の財政庁街, 西側の北土街, 南土街が拡幅整備されたのが大きい。道路拡幅とともに，大街に面 して，大規模な「商用集合住宅」が建設されていった。「商用集合住 宅」とは，一階を店舗とする集合住宅，日本でいう「下駄履き集合 住宅（アパート）」をいう。すなわち，21 世紀に入って，わずか数 年の間に地区は大変貌を遂げたことがわかる。保存地区指定を行い ながらの大改造であり，都市計画決定のちぐはぐさが露呈している ように思えるが, 表通りに比較すると, 学院門社区の内部は, 2000 年以前のかたちを比較的よく留めている。

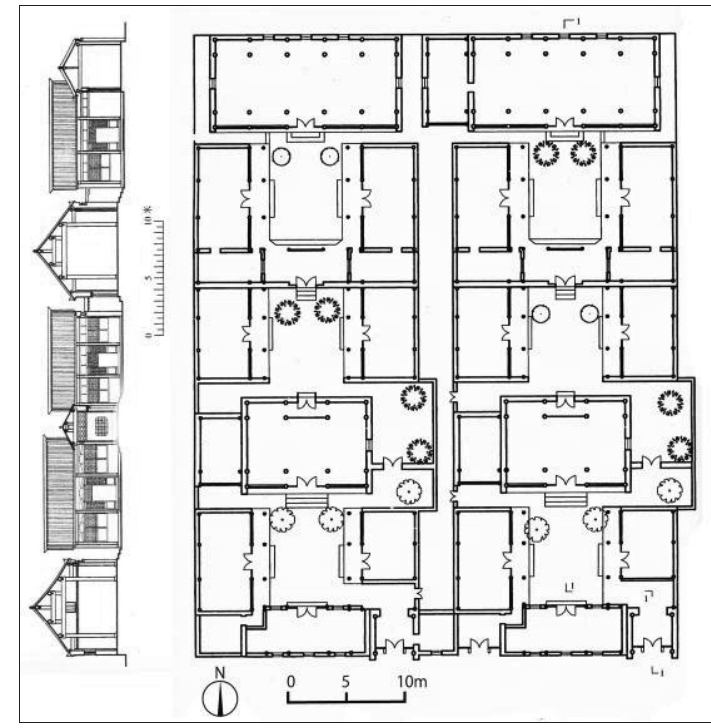

図 4 劉家住宅

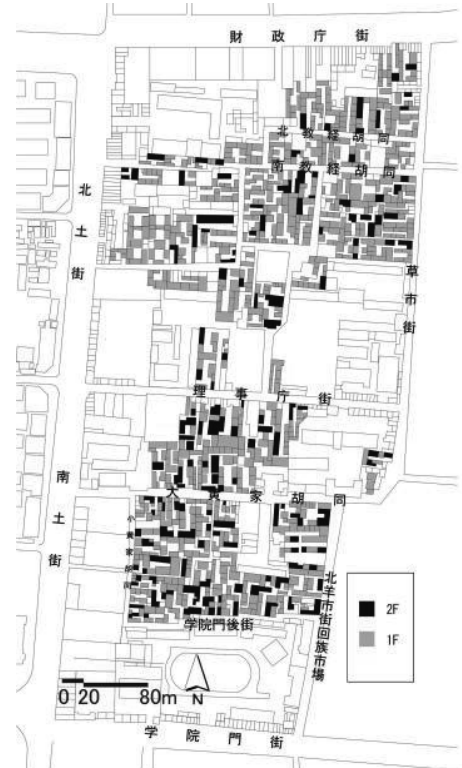

図 5

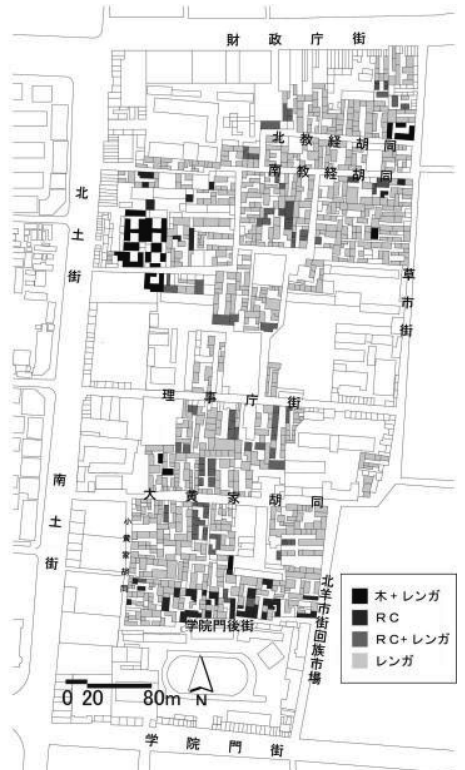

b 建築構造の分布 


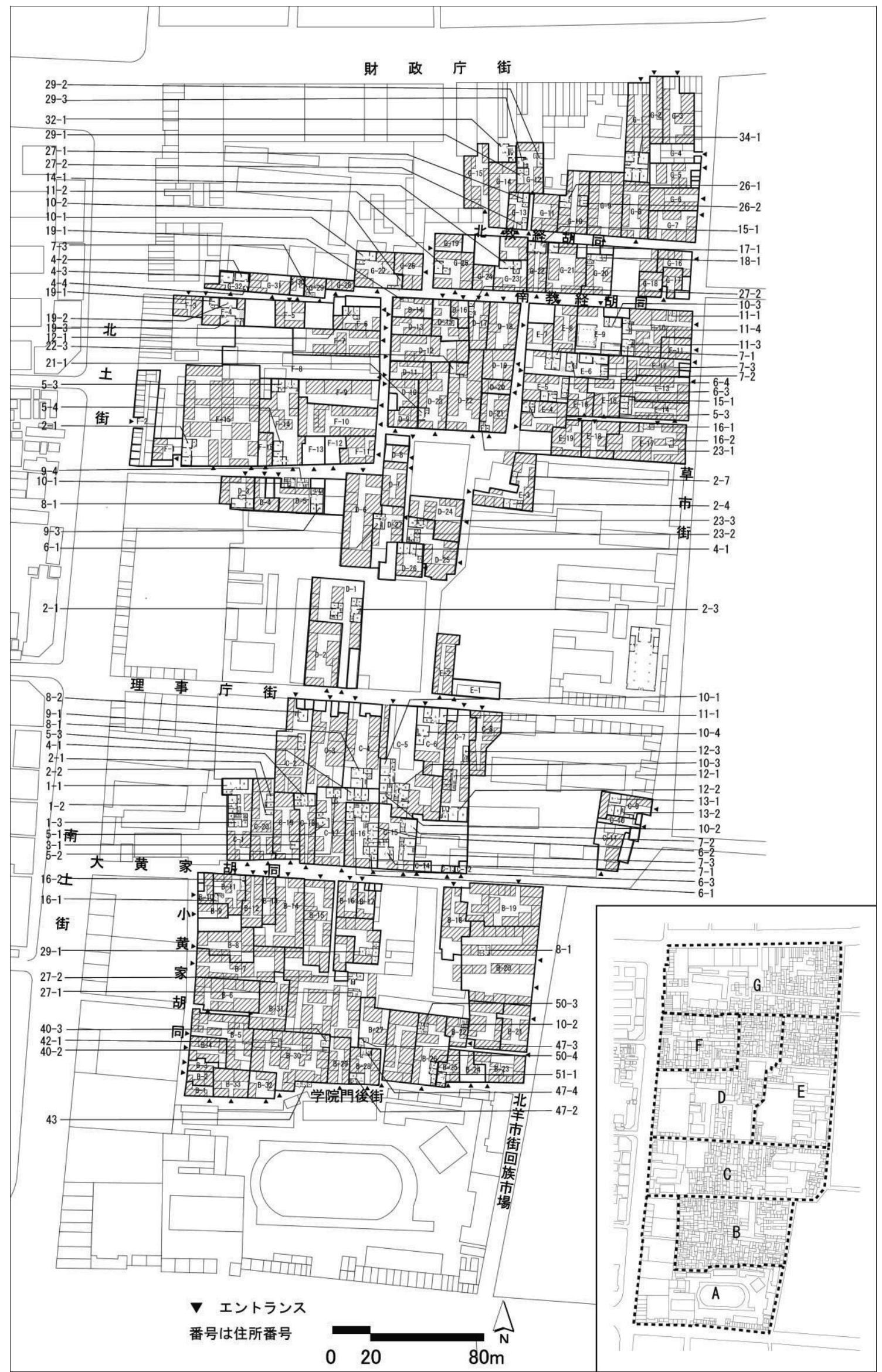

図 6 学院門社区の宅地形状と実測住居 


\section{3. 住居類型}

\section{3-1 住居の概要}

住居は，大きく専用住宅，店屋 (店舗併用住宅)，集合住宅，「商 用集合住宅」に分類できる。

専用住宅の原型となるのは, 四合院形式の住居である。残念なが ら, 開封城内に四合院はほとんど残っていない。調查地区に唯一残 っているのが劉家住宅である。劉家住宅は, 1880 年建設で, 三進 の同型の四合院 2 座（連棟）からなる（図 4)。西側の 1 号院は,

一進部分は住宅として使われているが，2３ 進は社区事務所にな っている。東の 2 号院は, 1 進部分は空家, 2 3 進部分は幼稚園に なっている。

「商用集合住宅」を除く, 専用住宅, 店屋（店舗併用住宅）につ いて, 建築構造と階数を示すと, 図 $5 \mathrm{ab}$ のようになる。学院門社区 の住居の構造形式は木造+煉瓦壁が $4.0 \%$ (36 件), RC 造+煉瓦壁が $5.8 \%$ (51 軒)， R C 造が 5. 8\%（51 軒），煉瓦造が 84.6\%（759 軒） であり, 大多数を煉瓦造が占める。住居の階数については， 1 階建 が $75.4 \%$ (676 軒)，2 階建が 24.6\%（221 軒）であり，1/4 が平屋 の住居である。

大多数の専用住宅は平屋であり, 街区の内部に数多く分布する。 四合院は崩れ, 数世帯が居住するいわゆる「大雑院」と化している。

\section{3-2 宅地の規模と類型}

学院門社区には, 専用住宅, 店屋（店舗併用住宅）について 146 の宅地が確認できる（図 6)。

敷地形状によって異なるが, 間口方向最大幅, 奥行方向最大長さ をそれぞれ間口, 奥行としてみると, 間口は平均 $17.6 \mathrm{~m}$ （最大 $53.5 \mathrm{~m}$, 最小 $4.74 \mathrm{~m})$, 奥行は平均 $27.6 \mathrm{~m}$ (最大 $88.0 \mathrm{~m}$, 最小 $3.72 \mathrm{~m}$ ) である。その分布は図 7 ようになる。

劉家住宅の場合， 1 号院と 2 号院を合わせると，間口 $42.0 \mathrm{~m}$, 奥行 56. 3m である。宅地については, ほぼすべての宅地の面積は劉家住 宅より小さいことがわかる。2 進の四合院は間口約 $20 \mathrm{~m} \times$ 奥行約 50 数 $\mathrm{m}$ と考えられ，この宅地を標準型とすると，奥行がおよそ半分に なっているから，敷地面積はほぼ 2 分割されてきたと想定される。

宅地の形状は 4 つに分類できる（表 1）。

a. 基本型 : 矩形の敷地。

b. L 字型 : 矩形の敷地の後部の一部が分割されるもの。

c. 一字型 : 矩形の敷地の前部の一部が分割されるもの。

d. L一字型 : 矩形の敷地の前部の一部および後部の一部が分割 されるもの。

基本型は 49 筆，全体の $33 \% ， \mathrm{~L}$ 字型は 51 筆，全体の $34 \%$ を占め る。一字型は 25 筆，全体の $17 \%$ ， L 一字型は 21 筆，全体の $14 \%$ で

\section{表 1 宅地形状の類型}

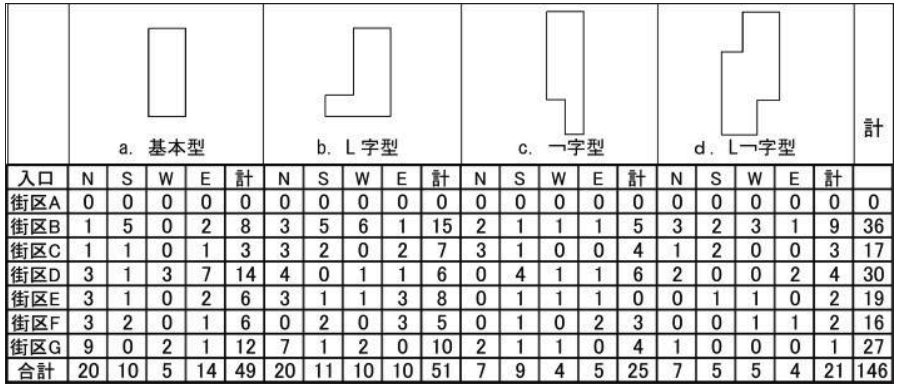

ある。一般的には街路に面することが優先されている。

敷地へのアプローチ（入口）は，街区を分ける街路によるが，北 が 54 筆，南が 24 筆，西が 24 筆，東が 33 筆，北入りの敷地が多い。 西大街（財政庁街）が表通りとして意識されているといえる。

\section{3-3 住居の平面類型}

学院門社区は，居民委員会ごとに A, B, C, D, E, F, G の 6 街区に分 けられるが，実測調查を行った住居 103 世帯の内訳は，街区 A. 0

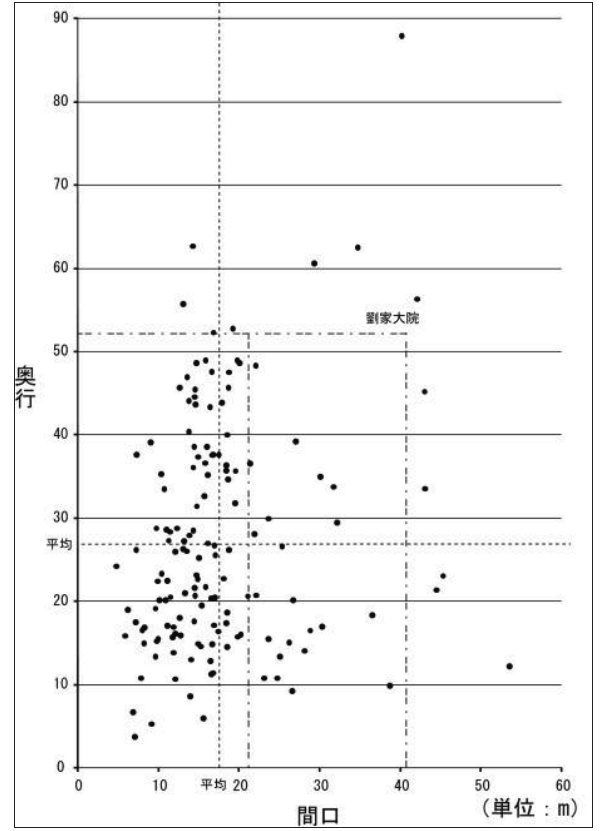

図 7 宅地規模の分布

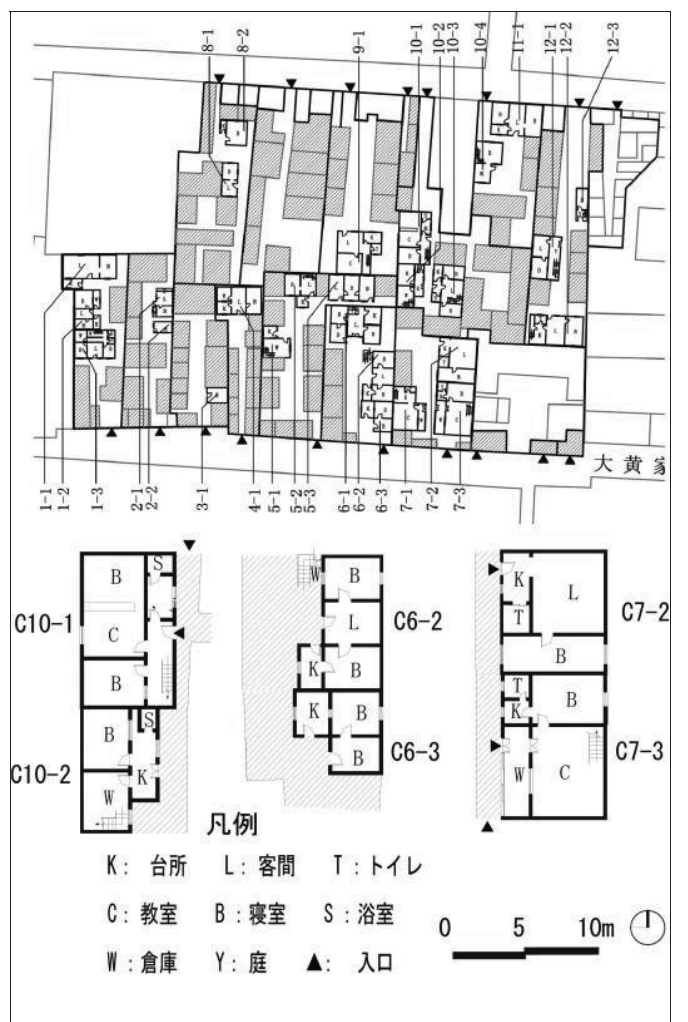

図 8 C 区の拡大図 


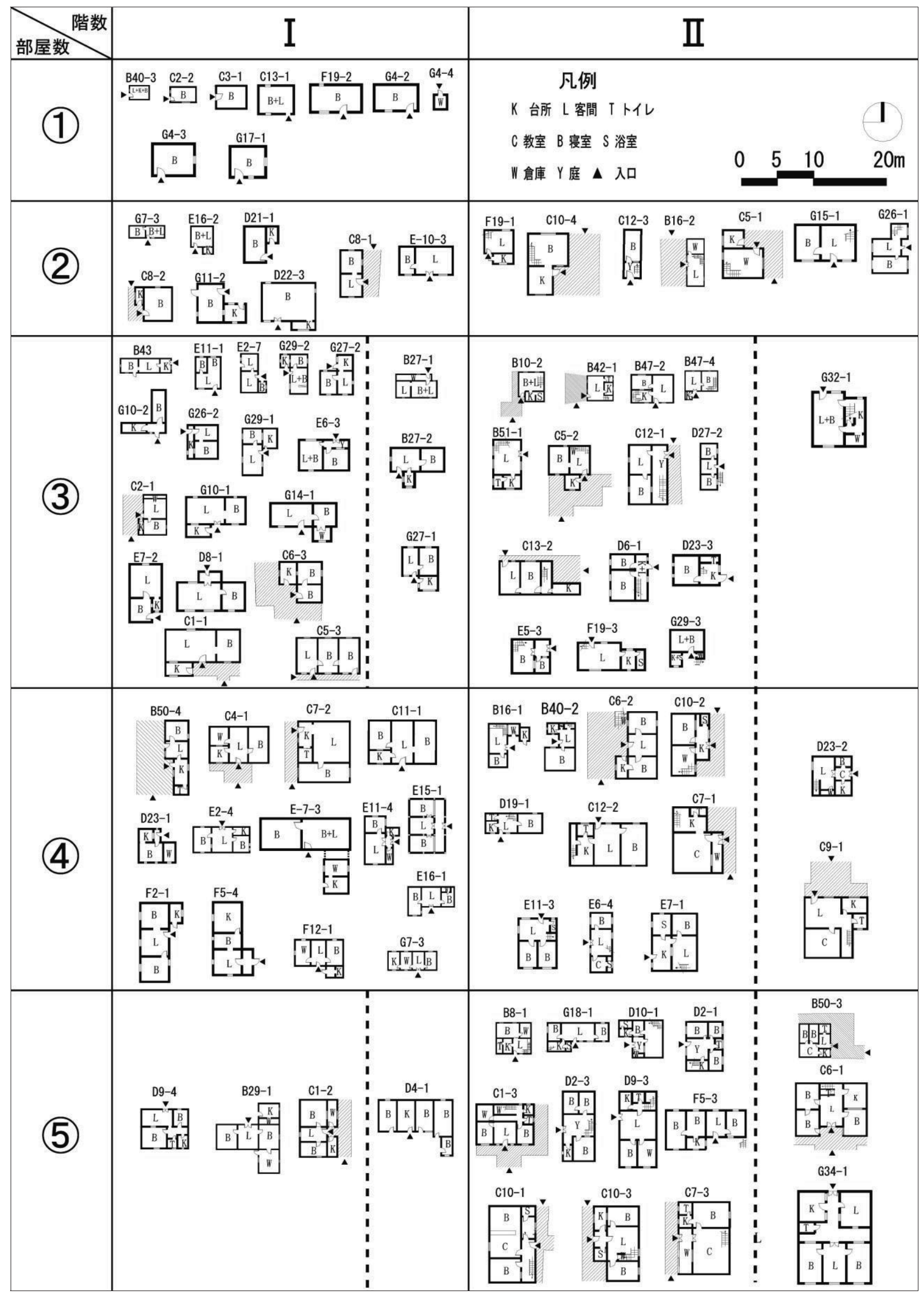

図 9 住居類型 
世帯, B. 17 世帯, C. 29 世帯, D. 15 世帯, E. 15 世帯, F. 7 世帯, G. 20 世帯である (図 6)。

敷地全体を 1 宅地とする例は, 劉家住宅を含めてなく, 全て大雑 院化している状態にある。

各宅地はいくつかの建物（棟）で構成されるが，1 棟に 1 世帯が 居住する例はわずかに 10 例（/103 例）であり，ほとんどの住居は さらに棟を分割するかたちで構成されている。C区を見ると（図 8) 6-2, 3，7-2，3，10-1, 2 はもともと 1 棟である。6-1，9-1，12-1 は 1 棟 1 世帯である。

103 の住居（世帯）を, A 1 階部屋数別, B 階数別, C 戸建か集合 住宅かの別に, その 1 階平面を示すと図 9 のように分類できる。平 屋が 56, 2 階建てが 48 である。1 階の部屋数については, 一室のみ のもの 9, 二室 15 (内 2 階建て 7, 以下同様), 三室 35（15）, 四室 26 (12), 五室 18 (14) となる。2 階について調査ができていないが, 基本的に居室として使用されていることがわかっている。

平面形式は多様であるが，およそ以下のような類型と系列を見出 すことができる。

一室住居（I１）には，様々な機能が持ち込まれるが，基本的に 寝室として用いられる。食事は外食となっている。二室住居（ I (2) は, 一室住居に㕌房が付加されるタイプ ( II (2)k) (C8-2, D21-1, D22-3, G11-2）と，居間ないし寝室を付加するものに分かれる。

二室住居は，上層（2 階）に部屋を拡大寸るもの（II (2)）と三室 住居（I (3)）へ向かうものとに分かれる。そして, 三室住居は二室 住居に厨房が付加されるかたち（ I (3)k）がほとんどである。この戸 建型（B27-2，G27-1）が成立しているのをみると，ひとつの住居型 と考えることができる。日本流にいうと $2 \mathrm{~K}$ である。

三室住居も, 内階段（あるいは外階段で）で 2 階に部屋を増築し ていくタイプ ( II (3)）と平面的に部屋などを付加するもの（ I (4)(5)） に分かれる。後者の場合, 付加されるのは, 寝室だけでなく, エン トランス (玄関), トイレ, 倉庫などがある。必要に応じて必要とさ れる部屋が付加されており, 必ずしも一定の型が成立してはいない。 2 階建て（II (3) (4)）となると, 戸建の例（C6-1，G34-1）のように明 快な形式をもつものがある。ただ，これは極めて少数の例であり， 学院門社区に一般的な形式として成立しているわけではない。

ただ，比較的大規模な住居（II (4)(5)）に整形（矩形）の住居形式 があり，一定の型が成立しているとみな寸こともできる。その特徵 は, かつての四合院の院子（中庭）から部屋（居間）に直接入るか たち(リビング・アクセス) をとることである (C12-2, D19-1, E11-3, E6-4, B8-1, C $1-3$, D9-3)。

\section{4. まとめ}

以上, 開封旧城内, かつての宮城南に位置する学院門社区につい て, その近年の変化を明らかにしたうえで, 宅地の形状, 住居類型 とその変容を明らかにした。その主要な点は以下である。

(1) 学院門社区は, 古来, 回族はじめユダヤ人など様々な民族が居 住してきたことで知られるが, 現在もキリスト教会, 清真寺などが 立地し, 回族が数多く居住するユニークなコミュニティが維持され ている。

(2)しかし，20世紀に入ってからの 10 年間, 特に世紀の変わり目 に行われた街路拡幅に伴う再開発による社区の変貌は急激である。
特に，高層の「商用集合住宅」の建設によって街区は大きく変化し つつある。しかし，全体として低層の住宅街区が維持されている。

(3)学院門社区には唯一四合院住宅である劉家住宅が残されている。 かつては, こうした四合院住宅が建ち並ぶ街区が形成されていたと 考えられるが, 街区内部の宅地について, その形状, 規模をみると, 細分化の進行は明らかである。平均的には, 二進の四合院が $1 / 4$ と なる変化が起こっている。ただ，宅地の中央部分に中庭あるいは通 路を設ける形式はほとんどの宅地において維持されている。

(4)住居は劉家住宅も含めて, かつての四合院形式をとるものは皆 無である。また， 1 棟で 1 住居となるかたちも極めて少ない。多く の住居は，棟を分割する形となっている。いわゆる大雑院と呼ばれ るかたちである。

(5)居住空間の構成は多様であるが，その規模が限定されているこ とから，一定の類型と系列を本稿で明らかにした。

以上のように, 大雑院化の進行は極限的である。西安や福建省な どの事例と比べると型の崩壊は著しい。この型の崩壊が，回族居住 者が支配的であることによるかどうかは，さらに調查研究が必要と 考える。

本稿作成にあたって、福州大学科研起動費の支援をしていただい てる（課題番号：035069）。

\section{参考文献}

1）伊原弘：中国開封の生活と歳時一描かれた宋代の都市生活, 山川出版社, 1991

2）伊原弘編：『清明上河図』を読む，勉誠出版，2003

3）伊原弘：中国都市の形象一宋代都市の景観を読む, 勉誠出版, 2009

4）入矢義高・梅原郁訳注 : 孟元老 東京夢華録一宋代の都市と生活, 東洋文 庫 1996

5）遠藤隆俊・平田茂樹 - 浅見洋二編：日本宋史研究の現状と課題一1980 年代以降を中心に一, 汲古書院, 2010

6) 久保田和男 : 宋代開封の研究, 汲古書院, 2007, 郭萬平訳-薰科校訳 : 宋 代開封研究，上海古籍出版社，2009

7）小岸昭：中国・開封のユダヤ人, 人文書院，2007

8）程子良：開封城市史，社会科学文献出版社，1993

9）周宝珠 : 宋代東京研究, 河南大学出版社, 1992

\section{注}

注1）文部科学省研究費補助金・基盤（B）2010-2012（代表者 布野修司） 他

注2）その名は，現在の開封の市街から $30 \mathrm{~km}$ 離れた古城村に建設された春秋 時代の鄭国の「啓封」城に由来する。「啓封」は「啓拓封疆」からきている とされる。漢代に県治が置かれるが, 景帝（劉啓）の諱を避けて「開封」 と改称された。

注3）朱全忠は即位した 907 年に開封を首都とするが， 2 年後に洛陽に遷都し ている。後唐もまた洛陽を首都とし, 洛陽を東都, 長安を西都, 太源を北 都，魏州を鄴都とした。後晋，後漢は，開封を首都としたが，郊壇，太廟 などの祭礼施設は洛陽に置かれていた。開封で郊祀が行われるのは, 後周 以降である。

注4）趙冲, 于航, 布野修司, 川井操「開封旧内城の空間構成とその変容に 関する考察一文殊寺・学院門社区の都市組織一」, 日本建築学会計画系論文 集, 第 78 巻, №. 685, pp519-526, 2013 年 3 月

注5）北宋末の張擇端が開封をテーマに描いたとされる風景画。「清明上河図」 と題された画巻は数多く描かれ 40 巻を超える。

注6）孟元老による北宋の首都，汁京の繁盛記。記録されたのは，北宋最後の 皇帝徽宗の治下，12 世紀初頭である。

注7) 于航: 開封の空間構成とその変容に関する研究, 滋賀県立大学修士論 文, 2012 年

注8）調査参加者は于航，榎本雅司，趙沖，布野修司である。 


\title{
CONSIDERATIONS ON HOUSE TYPES OF XUE YUAN MEN SHE QU \\ (KAIFENG OLD CASTLE AREA) AND THEIR TRANSFORMATION
}

\author{
Chong ZHAO*, Shuji FUNO **, Misao KAWAI*** \\ and Ying $Z H A N G$ **** \\ * Lecture, School of Architecture, Fuzhou University, China, Dr. Eng. \\ ** Prof., Graduate School of Environmental Planning, University of Shiga Prefecture, Dr. Eng. \\ *** Assist. Prof., Graduate School of Environmental Planning, University of Shiga Prefecture Dr. Eng. \\ **** Prof., School of Architecture, Fuzhou University, China, Dr. Eng.
}

This paper discusses house types and their transformation of Kaifeng city in Henan (China), which is known as the capital city of Bei Son dynasty. Authors selected a she qu(Community) of former walled city in the central district of Kaifeng, which is called Xue yuan men she qu at present, as an intensive field study and clarified the types of dwelling units and the transformation process.

The spatial formation of Keifeng at Bei Song dynasty is identified on the present map based on the newest archeological findings. However Kaifeng at that time is buried several meters under the present ground level by many floods. The urban tissues we see now, is formed after flood in 1841. The central area of old castle was stil occupied by low rise houses and shop houses until the end of 20th century, but was drastically changed by redevelopment program introducing high rise apartment houses. This paper clarified the changes among decade 2000-2010 as for the targeted area. There existed old traditional form of siheyuan (Chinese quadrangle dwellings), siheyuan like Liu family residence which is only one example left in the area. Most of siheyuan had been destroyed or is shared by several families. This paper classified 103 dwelling units we measured into five groups according to number of rooms and discusses the extension process of living space. Most of siheyuan in the form of segmentation. What is dazayuan forms.

103 dwelling units plan formation is diverse. One room type( I (1)-Typically used as a bedroom. Two-room type( II (2))and Three-room type-Additional kitchen in the two room. Three-room type there are two layers of type additional housing( I (4)(5)). The larger type is rectangular plan. Although diverse types of housing, but its size is limited. 